\title{
Development of Science Process Skill for Chemistry Teacher Candidate Through Analytical Chemistry Learning with Guided Inquiry-Based and eXe Media
}

\author{
Anna Juniar \\ Doctoral Student of Chemistry \\ Education \\ Universitas Negeri Medan \\ Medan, Indonesia \\ anna.juniar@yahoo.com
}

\author{
Albinus Silalahi \\ Department of Chemistry Education \\ Universitas Negeri Medan \\ Medan, Indonesia
}

\author{
Retno Dwi Suyanti \\ Department of Chemistry Education \\ Universitas Negeri Medan \\ Medan, Indonesia
}

\begin{abstract}
This research was done to determine the effectivity of science process skill for chemistry teacher candidate which is gained by Analytical Chemistry practicum and determine the aspect of science process skill which able to be developed by using guided inquiry learning model in Analytical Chemistry with eXe Learning-integrated. The sample of this research was 2016's chemistry teacher candidate of Universitas Negeri Medan with A class as experiment class and B class as control class. The hypothesis of this research was tested by using $\mathrm{N}$-gain score. The result shown that effectivity of science process skill for chemistry teacher candidate which is gained by Chemistry Analytical practicum in the topic of Gravimetry and Titrymetry produced significant difference between eXe Learning-integrated and without eXe Learning. Moreover, $\mathrm{N}$-gain value was 0.8389 or $83.89 \%$ for eXe Learning with developed science process skill aspects were consisted of communicating in both writing and oral (95), planning the experiment (92), predicting hypothesis (90.9), interpreting the observation $(88)$, observing $(87)$, measuring $(83)$ also using tools and materials $(72)$.
\end{abstract}

Keywords—science process skill, analytical chemistry, eXe- Learning, guided inquiry.

\section{INTRODUCTION}

Nowadays, the quality of students' science mastering in Indonesia is not satisfied. This statement is proven by the result of PISA (Program for International Students Assessment) towards students in Indonesia from 2003 to 2015. In 2003, Indonesia was ranked 38th out of 40 countries [1]. In 2006, Indonesia was ranked 50th out of 57 countries [2]. In 2009, Indonesia was ranked 60th out of 65 countries [3]. The situation worsened in 2012, Indonesia was ranked 64th out of 65 countries [4] and in 2015 was ranked 62 of 70 countries [5]. These data show that the quality of mastering science in Indonesia is still low. This statement was also reinforced by the average score of National Science/ Chemistry Examinations in 2015 and 2016 respectively were 62.70 and 55.45 meanwhile in 2017 was 57.80 [6]. Nationally, the average value of science/ chemistry in Indonesia in 2016 was 55.79 [7].

As an effort to improve the quality of science mastering for teacher candidates, Universitas Negeri Medan as one of the Education Personnel Educators Institutions (LPTK) needs to prepare science/ chemistry teacher candidates with provision of science process skill, such that they are able to do profession as qualified and professional teachers. Students of science teacher candidates need to be equipped with integrated knowledge between the ability of study field and teaching science [8]. Science process skill involves cognitive or intellectual skill, procedural, social and communicative competence. Meanwhile, the abilities which developed in integrated skills are observing, classifying, interpreting, predicting, asking questions, hypothesizing, planning experiments, using tools/ materials, applying concepts and communicating [9]. The ability to execute integrated science process skills is related to deductive hypothetical problems [10], [11].

The difficulty problem of understanding First Analytical Chemistry lectures, especially Gravimetry and Titrymetry is appeared since it is loaded with calculations, concepts and applied discovery. If Analytical Chemistry is easily understood by teacher candidates, this will be a provision for the career development of chemistry teachers in the field and the laboratory activities become more positive, effective and improvable [12]. Solving this problem, guided inquiry learning model is designed to foster student's science process skill.

In this technological era, computer is useable as media and learning resources. The using of computer multimedia which combines several elements such as text, graphics, animation, sound and video may improve understanding of teacher candidate's students to conduct virtual lab activities as well as practicum in laboratories and eXe Learning [13]. The eXe Learning program is software which is used for learning systems of computers [14]. They must recognize the strengths and weaknesses of the appearance, content and use in learning such that they are not only enthusiastic about an interesting format, but more important is considering the accuracy of the concept. The using of ICT (Information, Communication and Technology) provides new opportunity in learning accompanied by the creativity of teachers and students, both in finding information, communication, 
virtual labs and interactive simulations in the laboratory [15]. Inquiry-based learning with laboratory activities is able to improve the mastery of the concept of teacher candidate' students in the form of concepts related to the subject matter being studied through a series of experimental activities [16]. In this paper, we will discuss how Analytical Chemistry learning which using guided inquiry and eXe Media is able to develop science process skill of chemistry teacher candidate.

\section{RESEARCH METHODOLOGY}

The design of this research is categorized as research and development of education (R \& D). The flow diagram of research is given in Fig. 1 below.

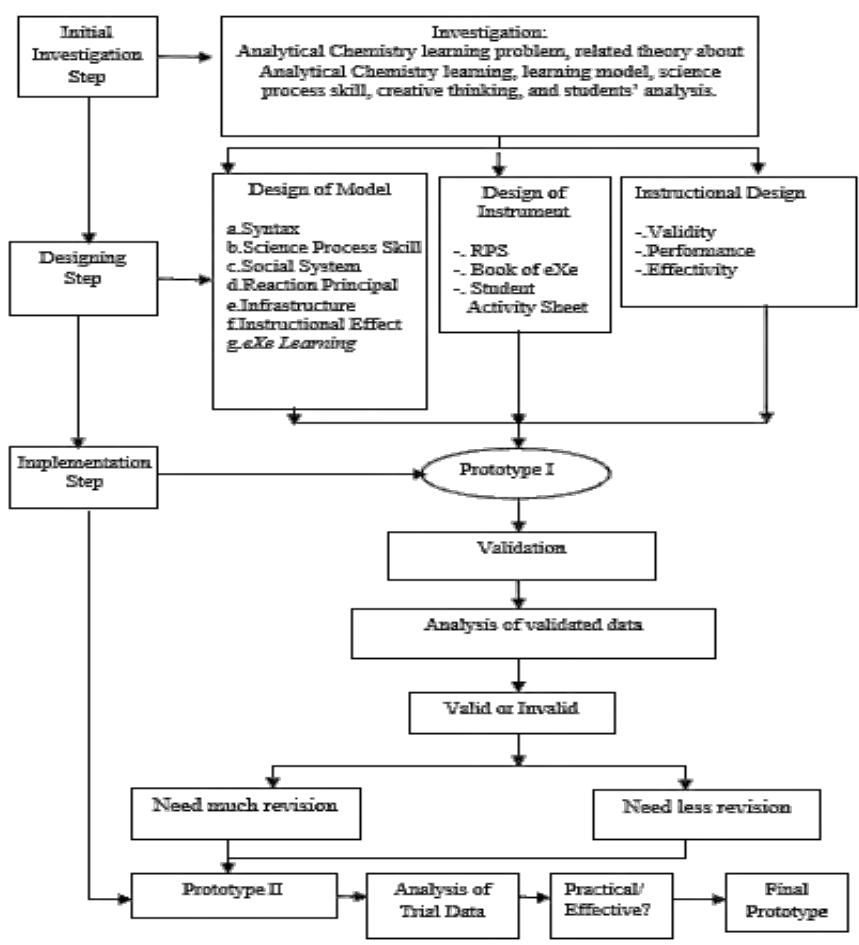

Fig 1. Flow Diagram Of Research

The location of this research was Chemistry Education Study Program of Universitas Negeri Medan at Jalan Willem Iskandar Pasar V Medan Estate. The sample in this study was the fourth semester students who took two courses in Analytical Chemistry, namely class A consisted 20 people and class $B$ consisted 20 people with total sample of 40 people. This research is also quasi-experimental type since using Pretest-Posttest Control Group Design. Qualitative data collection was obtained from the BSNP standard questionnaire while quantitative data collection was obtained from the test of learning outcomes and the ability of student processes during the Analytical Chemistry practicum.

Technique of data analysis which gained from students' learning outcomes (posttest value) was done by calculating $N$-gain which given by

$$
g=\frac{\text { Posttest Score }- \text { Pretest Score }}{\text { Maximum Score }- \text { Pretest Score }}
$$

with criterion of score:

a. Score $(g) \geq 0,70 \quad:=$ high.

b. Score $0,30 \leq(g) \geq 0,70:=$ intermediate.

c. Score $(g)>0,30 \quad:=$ low.

Meanwhile the effectivity of model is tested by using:

$$
\text { Effectivity }=\frac{g \text { Experiment Class }}{g \text { Control Class }}
$$

with Ho states there is no any difference of effectivity of model which given in the class and the criterion of hypothesis testing as below.

a. Ho is accepted when the value of effectivity $\leq 1$.

b. Ho is rejected when the value of effectivity $>1$.

\section{RESULT AND DISCUSSION}

A. The effectivity of science process skill for chemistry teacher candidate's which is gained by Analytical Chemistry practicum in Gravimetry and Titrymetry Topic

The students' process skill in Basic Analytical Chemistry practicum were determined by using essay tests and student worksheets. The score of posttest score and pretest score which used is the average of the posttest scores and the average pretest score for each class. The $N$-gain value for the Experimental Class is 0.8389 meanwhile in the Control Class is 0.7525 . So, we get the effectiveness of model is 1.1148 .

Since the value of effectiveness is $1.1148>1$, consequently $\mathrm{Ho}$ is rejected and $\mathrm{Ha}$ is accepted, which means there is a difference in the effectiveness of differences in science process skills of chemistry teacher candidates obtained through Analytical Chemistry I practicum in the topic of Gravimetry and Titrymetry. Based on the description above, it can be obtained the effectiveness of science process skills of chemistry teacher candidates obtained through Analytical Chemistry I practicum in the topic of Gravimetry and Titrymetry with the n-gain index value of 0.8389 or $83.89 \%$.

B. The aspect of science process skill which can be developed by using guided inquiry learning model in Analytical Chemistry with eXe Learning-integrated

In the basic analytical chemistry learning which was integrated with guided inquiry model, students were given 13 worksheets for one semester. The average of student scores is based on their performance during the practicum. The result shows that there are two of eight aspects of science process skills which have the highest score to be developed, namely aspect of communicating in writing and communicating orally with value of 95 . Table 1 below presents the scores students in learning Analytical Chemistry I. 
TABLE 1. AVERAGE VALUE OF STUDENTS WHICH LEARNING BY GUIDED INQUIRY MODEL

\begin{tabular}{|c|l|c|}
\hline No. & $\begin{array}{l}\text { Aspect of Science } \\
\text { Process Skill }\end{array}$ & $\begin{array}{c}\text { Average } \\
\text { Value }\end{array}$ \\
\hline 1 & Predicting hypothesis & 90.9 \\
\hline 2 & Planning the experiment & 92 \\
\hline 3 & Using tools and materials & 72 \\
\hline 4 & Measuring & 83 \\
\hline 5 & Observing & 87 \\
\hline 6 & Interpreting the observation & 88 \\
\hline 7 & Communicating in writing & 95 \\
\hline 8 & Communicating orally & 95 \\
\hline
\end{tabular}

Table 1 above shows that the ability of students to use tools and materials still needs to be improved. In gravimetric analysis, the accuracy in using analytical balance is very important to be noticed by students because the basic principle of analysis is based on mass calculations. Likewise, with volumetric analysis, using a burette as an instrument where standard solutions are accompanied by careful scale reading is the key to the success of quantitative analysis of a cation or anion contained in the sample. This greatly affects the accuracy of the results of the analysis. The same thing with observing indicators still need to be improved with earnest work so that truly accurate results are possible in quantitative analysis. To present aspects of science process skills which may be developed by students' chemistry teacher candidate, Fig. 2 below illustrates it.

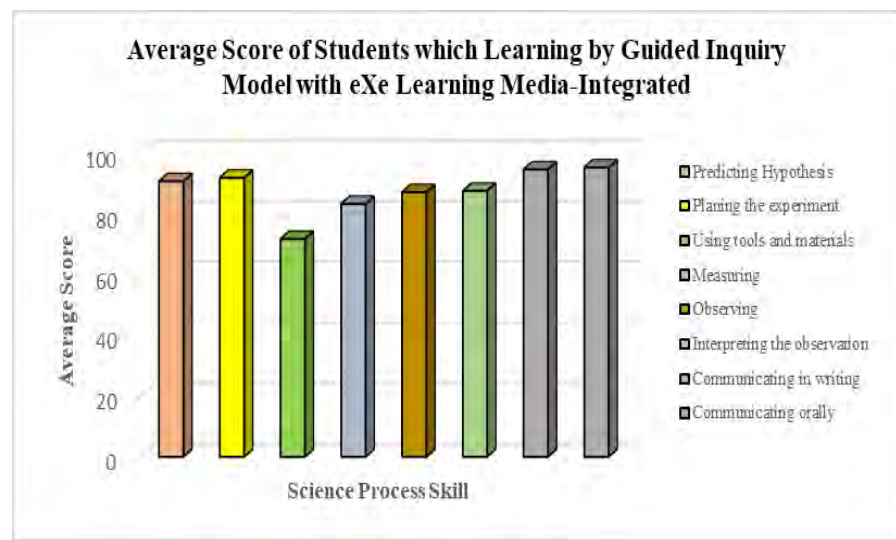

Fig 2. Average Score Of Student In Analytical Chemistry Learning By Guided Inquiry Model

Fig. 2 above shows the aspects of the science process skills of students' candidate teacher to communicate their practicum results both orally at the time they present in front of the class and in the discussion group group got the highest score. This is possible happened because they were really working carefully on mini-research and projects which was given by the lecturer as the implementation of the KKNI curriculum. Likewise the time communicating in writing through the practicum report contained in student worksheets, students are also careful when writing down chemical reactions which accompanying the process of analysis and identification of cations, anions and analytes in the samples given to each of them in their groups.

\section{CONCLUSION}

1. The effectiveness of science process skill of chemistry teacher candidates which obtained through Analytical Chemistry practicum on Gravimetry and Titrymetry topic produces value $1.1148>1$ means $\mathrm{Ha}$ is accepted. It means there is a difference in the effectiveness of chemistry teacher candidates who are taught with eXe learning without eXe learning, with $\mathrm{N}$-gain value is $83.89 \%$.

2. The aspects of science process skill which can be developed are communicating in writing and orally (95), planing experiment (92), predicting hypotheses (90.9), interpreting observation (88), observing (87), measuring (83), also using tools and materials (72). Furthermore, in this research communicating aspect is the most affected by applying guided-inquiry model with eXe learning.

\section{ACKNOWLEDGMENT}

In this section, the authors would like to thank for Direktorat Riset dan Pengabdian Masyarakat Direktorat Jenderal Penguatan Riset dan Pengembangan Kementerian Riset, Teknologi, dan Pendidikan Tinggi for funding the research by program "Hibah Program Doktor".

\section{REFERENCES}

[1] OECD, PISA 2003 technical report. PISA: OECD publishing, 2005.

[2] OECD, PISA 2006 science competencies for tomorrow's world. PISA: OECD publishing, 2009.

[3] OECD, PISA 2009 executive summary. PISA: OECD publishing, 2010.

[4] OECD, PISA 2012 results in focus: what 15-year-old know and what they can do with what they know. PISA: OECD publishing, 2014.

[5] OECD, PISA 2015 programme for international student assesment (PISA) results. PISA: OECD publishing, 2016.

[6] Kementerian Pendidikan dan Kebudayaan, Indikator mutu dalam penjaminan mutu pendidikan dasar dan menengah. Indonesia: Direktorat Pendidikan Dasar dan Menengah, 2017.

[7] Unit Kerja Presiden Bidang Pengawasan Pengendalian Pembangunan (UKP-PPP), online accessed at May 1st, 2017, 01.15 PM from website: data.go.id/organisation/kemendikbud, 2016.

[8] Karamustafaoglu, S. "Improving the science process skills ability of science student teachers using i diagrams," in Eurasian Journal of Physics and Chemistry Education, 2011, vol. 3(1), p. 26-38.

[9] Rustaman, N.Y., "Perkembangan penelitian pembelajaran berbasis inkuiri dalam pendidikan sains". Presented in Seminar Himpunan Sarjana dan Pemerhati Pendidikan IPA Indonesia III (HISPPIPAI), Bandung, July 22-23, 2005.

[10] Uma, F.A., Subiyanto H., and Endang S., "Pengembangan lembar kerja praktikum siswa terintegrasi guided inquiry untuk keterampilan proses sains" in Chemistry in Education by Unnes, Vol. 4(1), p. 55, 2015.

[11] Yildrim, M., "A meta-synthesis of turkish studies in science process skills," in International Journal of Environmental \& Science Education, Vol 11(14), pp. 6518-6539, 2016. 
[12] Ceylan S. and Gülşah S.V., "The impact of inquiry based instruction on science process skills and self-efficacy perceptions of pre-service science teachers at a university level biology laboratory," in Universal Journal of Educational Research, Vol 4(3), 603-612, 2016.

[13] Neil F. and Luisa L., "Using presentation software to flip an undergraduate analytical chemistry course". In Journal of Chemical Education, Vol 92, pp. 1559 - 1563, 2015.

[14] Ivo L., Irja H. and Lauri J., "Using MOOCs for teaching analytical chemistry: experience at university of tartu," in Anal Bioanal Chem, Vol 407, pp. 1277-1281, 2015.
[15] Natasa, R. H. and Dejan D., "Virtual laboratory in chemistryexperimental study of understanding, reproduction and application of acquired knowledge of subject's chemical content," in Organizacija Research Paper, Vol 45(3), 109, 2012

[16] Sesen. B. A. and Tarhan L., "Inquiry-based laboratory activities in electrochemistry: high school students' achievements and attitudes," in Research Science Education, Vol. 43(1), 190-435, 2013. 